\title{
Analysis of Eight Grade Students Performance in Solving Mathematical Representation Problems
}

\author{
Ani Minarni \\ Department of Mathematics \\ Universitas Negeri Medan \\ Medan, Indonesia \\ e-mail: animinarni10@gmail.com
}

\begin{abstract}
This research is conducted to contribute in improving students' achievement in Mathematical Representation Ability (MRA) and their performance in solving MRA problems. Those involved as samples are 316 students from Public Junior High School (PJHS) 1, PJHS 2, and PJHS 4 District Deli Serdang, and PJHS 17, PJHS 19 Medan City. Joyful Problem-based Learning (JPBL) is implemented to attain the purpose of the research. Students' achievement in MRA is measured through MRA test scores. The scores is analyzed through Student-t test at 0.05 significant level. Students' performance in solving MRA problems is analyzed descriptively. Results of the research: (1) Students in JPBL class get better MRA achievement than their counterpart in conventional one, (2) The students' performance in solving MRA problems is better in JPBL class than that of their counterpart in Conventional one. The students faced the difficulties in two aspect of MRA: Present the problem in figures and give explanation, especially related to graph and table. Meanwhile, the students' performance is best at the aspect of present the problems in mathematical equation, (3) MRA of the students in JPBL class significantly improved.
\end{abstract}

Keywords: Mathematical Representation Ability (MRA), Joyful Problem Based Learning.

\section{INTRODUCTION}

Listed in National Education Standards Agency [1] that mathematics is a universal science and underpin the development of modern technology, has important role in fostering the ability to think. Mathematics is given to students aiming for them to have a number of abilities, namely to understand mathematical concepts, to use reasoning in solving mathematical problems, to communicate ideas in various forms of mathematical representation, and to have a tenacious and confident [1]. In addition, the curriculum and evaluation standards for school mathematics [2] stated that mathematics is the central focus, characterized by its power in modelling, and communicating the concepts and relationship in the sciences and technology. Mathematics is a tool of science and technology, essential for carrying out and describing the process and outcomes of theoretical and empirical investigations. Then, it is logical if students from grade I to grade XII should learn mathematics [2].
Through learning and doing mathematics the students develop thinking skills and solving various kind of problems. As mentioned in NCTM [2], solving problems or working on math problems are quite complicated and challenging, the students can grow appreciation for mathematics, realize the value of mathematics, discipline, obedience, consistence, patience, tenacious, and abstinence giving up, thinking logically, analytically, systematically, critically and creatively. Thus, it is make sense if problem solving becomes the main goal of learning mathematics.

Actually, problem solving is the process of applying knowledge into new and unfamiliar situation [4]. Kilpatrick mentioned that problem solving is an integral part of mathematical proficiency [2]. If students proficient in mathematics, then he/she is capable in problem solving, reasoning, conceptual understanding, and has mathematical disposition. Whenever the students develop mathematical problem solving, then mathematical understanding and representation will be developed [5][6]. In turn, the ability of mathematical understanding [7] as well as mathematical representation ability [8] as the prerequisite for the smoothness of problem solving will grow as well. Thus, it is a must to give the opportunity to the students engage in solving problems.

Problem-solving skills as one of high order thinking skills could not achieve by the students through Conventional teaching learning that characterize with a teacher as a center of learning [9]. In fact, the achievement of Indonesian students in solving mathematical problems, where Conventional teaching learning used until now, is low [10]. Thus, it is urgent to implementing student-center learning with constructivism as a theoretical background, because of the principle of this approach is to promote the students to be actively engage in developing their own knowledge and rediscover the concepts of mathematics as well. One kind of such learning is ProblemBased Learning (PBL)[11]

Integrating joyful learning [12] into PBL yield effective learning approach, namely Joyful Problem-based Learning (JPBL) [8][13]. On one side, PBL designed to improve 


\section{RESULT AND DISCUSION}

One of the interesting result of the research is the following discussion taken place the process in attaining the solution for problem 1 in SAS. The problem is about finding the relationship between age and weight of a baby. This activity took place after students' group discusion faced difficulty to finish the task. They can no longer continue the task of solving problem. On one side, the difficulty faced by the students showed that they need more scaffolding from the teacher. But then the conversation shows students' good engagement in learning process.

\section{Problem 1 : Weight and age of a baby}

$\mathrm{S}_{\mathrm{i}}=$ Student-i, $\mathrm{i}=1,2 \ldots, 32$.

$\mathrm{T}=$ Teacher; $\mathrm{D}=$ Dicky

$\mathrm{N}=$ Nurul; $\mathrm{A}=$ Azizah; $\mathrm{F}=$ Fikri

$\mathrm{Gi}=$ Group $\mathrm{i}, \mathrm{i}=1,2,3, \ldots, 8$.

$\mathrm{T}$ : Look at problem 1 in your SAS. Who knows, what is $x$ in this problem?

$\mathrm{D}$ : Weight of a baby.

$\mathrm{N}:$ No....., it is baby' age.

$\mathrm{D}:$ Oh yes, sorry.

$\mathrm{T}:$ It's OK. Then, what is $y$ ?

$S$ : Average weight of baby.

$\mathrm{T}$ : That's right. Try to find the relationship ot these two variables. Who knows how to see this relationship?

$\mathrm{G}_{1}$ : We put it in this table:

\begin{tabular}{|c|c|c|c|c|}
\hline$y$ (kg) & 3000 & 3300 & 3600 & 3900 \\
\hline$x$ (month) & 1 & 2 & 3 & 4 \\
\hline
\end{tabular}

$\mathrm{T}$ : And then? Aha, one of your friend represent it in stem \& leaf digaram. Good. Go on find the solution. I give you all ten minutes to discuss it further.

$\mathrm{G}_{2}$ : We have this table, mam...:

\begin{tabular}{|c|c|c|c|c|}
\hline$y$ & $3000+0$ & $3000+300$ & $3000+600$ & $3000+900$ \\
\hline$x$ & 1 & 2 & 3 & 4 \\
\hline
\end{tabular}

$\mathrm{G}_{3}$ : We got this table, mam...:

\begin{tabular}{|c|c|c|c|c|}
\hline$Y$ & $(1)(0)+3000$ & $\begin{array}{c}(1)(300) \\
+3000\end{array}$ & $\begin{array}{c}(2)(300) \\
+3000\end{array}$ & $\begin{array}{c}(3)(300) \\
+3000\end{array}$ \\
\hline$X$ & 1 & 2 & 3 & 4 \\
\hline
\end{tabular}

$\mathrm{G}_{3}$ : Aaah, I got it.

$\mathrm{T}$ : What did you got?

$\mathrm{G}_{3}$ : This one, mam..... Another table.

\begin{tabular}{|c|c|c|}
\hline$y$ & $(1-1)(300)+3000$ & $(2-1)(300)+3000$ \\
\hline$x$ & 1 & 2 \\
\hline
\end{tabular}

\begin{tabular}{|c|c|c|}
\hline$y$ & $(3-1)(300)+3000$ & $(4-1)(300)+3000$ \\
\hline$x$ & 3 & 4 \\
\hline
\end{tabular}

$\mathrm{G}_{3}$ : Horeee...., the equation is $y=(x-1) .300+3000$.
$\mathrm{T}$ : Yeah, you are all expert in solving problem!

$\mathrm{T}$ : Thus, what is average weight of baby at age 5 ?

$\mathrm{G}_{4}: y=(5-1) \cdot 300+3000=4.300+3000$ $=1200+3000=4200$ grams.

$\mathrm{T}$ : The solution proposed by group 4 is wright. Is there another of you has other solution?

A: How very light baby he is.

He should be 7 kilograms.

$\mathrm{S}_{3}$ : He certainly did not eat well.

$\mathrm{S}_{4}$ : Maybe his parent is poor...couldn't buy nutritious food.

$\mathrm{S}_{\mathrm{i}}$ : hahaha....

$\mathrm{T}$ : OK. Enough. Then you should be thankful to eat well.

$\mathrm{G}_{5}$ : Mam, we will do another problems.

F : Mam, I still don't understand anything. I don't know what to do.

$\mathrm{T}$ : Ask your friend first. Then, I'll give you special hint, Fikri.

$\mathrm{F}$ : Thanks mam...

$\mathrm{T}$ : Look another problem and try to understand what the problem is. You must eager to solve the rest of the problems, so you can become a good problem solver.

$\mathrm{S}_{\mathrm{i}}$ : OK maaam..

$\mathrm{T}$ : Good luck...

\section{Problem 2 : Mathematical equation of a line}

$\mathrm{T}:$ Look at Figure 3

$\mathrm{T}:$ What is an equation for line $k$ ?

$\mathrm{S}_{1}$ : We will find it, mam. Wait a minute.

Almost every student is busy, discussing the problem.

After 5 minutes, one of the students propose the equation.

A : Eeem, $4 x+4 y=4$ for line $k$.

$\mathrm{S}$ : That's wrong...

$\mathrm{T}:$ Sssssstttt.... Why you propose that equation, Azizah?

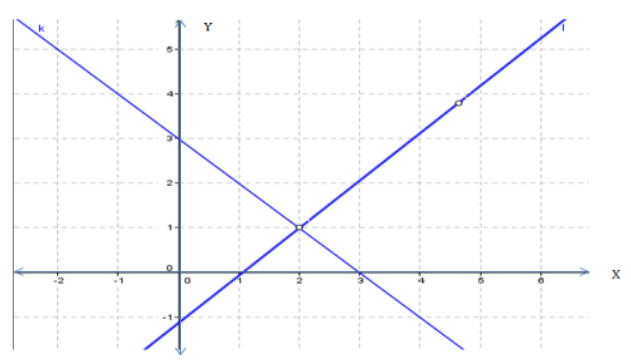

Figure 2

A : Because that line passes trhrough $x=4$ and $y=4$.

$\mathrm{T}$ : Azizah, reconsider your result, OK. Discuss with your group.

$\mathrm{S}_{2}:$ Mam...., line $k$ is $\mathrm{y}=x+4$.

$\mathrm{T}$ : Can you check your equation, whether is it true?

$\mathrm{S}_{2}$ : Yaa...for $x=4$, we have $y=4+4=8 \ldots$

Ooh, this one mam $y=-x+4$

$S$ : Huuuuh

$\mathrm{T}:$ Quite, please.

$\mathrm{S}_{2}$ : Ya, for $x=4$, we have $y=-4+4=0$.

$\mathrm{T}:$ Good.

$\mathrm{S}_{3}:$ For $y=4$, we got $4=-x+4$, so, $x=0$

$\mathrm{T}$ : Ecxelent.

$\mathrm{S}_{4}$ : Mam, it means the line passes trough point $(4,0)$ and $(0,4)$. 
Is it right?

$\mathrm{T}:$ Confirm it to your friend first.

$\mathrm{S}_{3}$ : Yes, line $k$ passes through that points.

$\mathrm{T}$ : Continue to solve the rest of the problem, OK.

$\mathrm{S}$ : Oke maaaaam.

$\mathrm{T}:$ Listen to me and look at problem number 3 about price of a pencil.

$\mathrm{T}$ : The price of tree pencils and two erazers is 13.000 rupiahs. The price of 4 pencils pencils and tree erazers is 18.000 rupiahs. What is the price of a pencil?

$\mathrm{T}:$ What will we do first to solve this problem?

$\mathrm{S}_{6}$ : Put it in graph.

$\mathrm{T}:$ OK. Try it.

$\mathrm{S}_{5}:$ Create a table first.

$\mathrm{T}:$ For what?

$\mathrm{S}_{5}$ : To get two points from each equation.

$\mathrm{S}_{7}$ : Define an equation first.

I got $3 p+2 e=13.000$

$$
4 \mathrm{p}+3 \mathrm{e}=18.000
$$

$\mathrm{G}_{4}$ : We think, its simpler to write

$$
\begin{aligned}
& 3 p+2 e=13 \\
& 4 p+3 e=18
\end{aligned}
$$

$\mathrm{T}$ : Alright, but don't forget to multyply the solution to 1.000 .

$\mathrm{T}$ : Yuup, how can we get the value of $\mathrm{p}$ ?

$\mathrm{S}_{5}:$ Suppose $4 \mathrm{p}=18-3 \mathrm{e}$

$$
\mathrm{p}=\frac{18-3 \mathrm{e}}{4}
$$

$\mathrm{G}_{2}$ : Then, we substitute $\mathrm{p}$ to the first equation.

$\mathrm{T}:$ Great!

$\mathrm{T}$ : Can you solve it overall?

G : We'll try, mam..

$\mathrm{G}_{2}$ : Heeeemmm....we found $\mathrm{p}=4$ and $\mathrm{e}=2$.

T: Good. Can group 8 check this answer. Is it true or not?

$\mathrm{G}_{8}$ : We have not got the answer yet, mam..

$\mathrm{T}$ : Group 1?

$\mathrm{G}_{1}$ : We're trying another way. We create graph. $\mathrm{T}$ : Continue your work

After a moment:

$\mathrm{G}_{1}$ : Mam, we got this table.

\begin{tabular}{|l|c|c|c|}
\hline $3 \mathrm{p}+2 \mathrm{e}=13$ & $\boldsymbol{P}$ & $\boldsymbol{e}$ & $(p, \boldsymbol{e})$ \\
\hline & 0 & 6.5 & $(0,6.5$ \\
\hline & 4.33 & 0 & $(4.33,0)$ \\
\hline $4 \mathrm{p}+3 \mathrm{e}=18$ & 0 & 6 & $(0,6)$ \\
\hline & 4.5 & 0 & $(4.5,0)$ \\
\hline
\end{tabular}

$\mathrm{T}:$ So, based graph, what is the solution?

$\mathrm{G}_{1}$ : Common point for these two line is $(3,2)$

$\mathrm{T}:$ So...

$\mathrm{G}_{1}$ : The solution is $\mathrm{p}=3$ and $\mathrm{e}=2$.

$\mathrm{T}$ : Check again your work to assure the solution is true.

$\mathrm{T}$ : Two group give the same solution, another one gives different solution.

Right solution is $\mathrm{p}=3000$ and $\mathrm{e}=2000$.

$\mathrm{G}_{1} \& \mathrm{G}_{2}$ : Hooraay, we win.

$\mathrm{T}:$ How about group 6 ?

$\mathrm{G}_{6}$ : Trying another methods, mam.
$\mathrm{T}:$ What kind of methods?

$\mathrm{G}_{6}$ : Elimination.

$\mathrm{T}:$ Go on.

$\mathrm{G}_{7}$ : By elimination, we got $\mathrm{p}=3$ and $\mathrm{e}=2$.

$\mathrm{T}$ : Group 7 got different solution from group 2 .

Whose solution is true?

$\mathrm{S}$ : ............mmm....

$\mathrm{T}$ : Aaah how wonderful you all.

$\mathrm{T}$ : You all have trying tree techniques to solve the system of linear equation of two variables: Graph, Substitution, and Elimination techniques. You are all great.

$\mathrm{T}:$ I'll give you a........gift.

$\mathrm{S}$ : What kind of gift, mam...

$\mathrm{T}$ : Delicious candy...

S : Ah...ya. We like candy.

$\mathrm{T}$ : Just finish your work first, OK.

$\mathrm{S}:$ Ha..ha..ha.......

$\mathrm{G}_{4}$ : Mam, we haven't understood anything yet.

$\mathrm{S}_{20}: \mathrm{Me}$, too.

$\mathrm{T}$ : Don't worry, one of the group will describe the solution on the board. So, keep full attention to them, OK.

T: Listen to your friend's explanation. You are free to give feedback and correction to your friend presentation.

Even ask their idea you do not understand.

Through group work and discussion, the students inculcate mathematical representation ability. Students' achievement in MRA is measured trough MRA test score.

\section{Students' achievement}

RMA score is used as a basis to determine the achievement of students' mathematical representation ability.

TABLE 2 Statistics of MRA Score

\begin{tabular}{|c|c|c|c|}
\hline Approach & $\mathbf{N}$ & Mean & SD \\
\hline Conventional & 158 & 6.70 & 1.097 \\
\hline JPBL & 158 & 12.21 & 1.981 \\
\hline
\end{tabular}

Table 2 shows the difference of MRA average score between the students in JPBL class and Conventional one. The students' MRA in JPBL class is different from that of the students in conventional class.

TABLE 3. Output of t-Independent test for MRA

\begin{tabular}{ccccc}
\hline \multicolumn{5}{c}{ TABLE 3. Output of t-Independent test for MRA } \\
Df & T & Sig. & Mean difference & $\begin{array}{c}\text { STD } \\
\text { Mean diff. }\end{array}$ \\
\hline 314 & 28,398 & 0.000 & 5.335 & 0,186 \\
\hline
\end{tabular}

The result of Student-t test shows in Table 3 pointed out that the achievement of the students in JPBL class is better than that of in Conventional one. As conclusion, JPBL gives significant effect to the students' MRA achievement. This finding is consistent with the latest research that joyful PBL is effective in improving the ability of mathematical representation of junior high school students [8][13]

Rationale for this achievement is that learning approach based on JPBL has a syntax that allows the students actively engage in constructing their own mathematical concept through solving various mathematical problems. Besides, 
teacher provides scaffolding gradually to the students who have obstacles in understanding the problem or stuck at any phase before arrived to the solution. Furthermore, based on observation the teacher approximately $87 \%$ do implement every aspect of learning approach. Teachers motivated students' engagement in group-work in order to solve problems contained in Student Activity Sheets (SAS), as well as guided to the source of information. Mathematics books designed based on JPBL are available for both students and teachers.

\section{Student Performance}

Investigation towards the solution given by the students in every aspect of mathematical representation capability reveals that students have difficulties at the aspect in creating picture that can make them easier to get the solution and giving reasons or explanations for the solution they get in accordance with the initial problem. The results of interview showed that the students faced these difficulties because of forget the following thing: the concept of distance and the concept of Cartesian diagram. These are mathematical prior knowledge (MPK) the students must have. Lack of MPK in line with result of Minarni former research [8].

Another reason, some of the students are lazy to make pictures or any other graph representation doe to they think math problem can solve without the help of these representation. It means that the persistence to master the skills of presenting the problem in a picture of an image has not entailed yet as a habit of the students, whereas the teacher continuously inculcated this skill throughout the course of the JPBL-based learning supported by problems in SAS. It seems, to flourish good habit need support of core family and environment, not just support from teacher, friends, and school.

Like developing good habit, develop mathematical representation ability of the student is also not as easy as our imagination. It needed teacher' dedication and teacher selfconfidence to apply JPBL appropriately. The finding inspired us as teachers to be serious in giving more exercise that elicit the ability of the students to present or represent the problem in pictures or other types of representation. Creating pictures of various mathematical problems give advantage to the students to see how powerful and beautiful mathematics is, and in turn develop imagination and harvesting students' interest in solving mathematical problem.

An example of Post-test problem is presented in Figure 2. As a whole, many students no longer find it difficult to create pictures, graphs, tables, or mathematical equations. Even, most students have been adept at creating mathematical equations as one of mathematical representation' aspects.

$$
\begin{aligned}
& \text { Look at the four pairs of straight line below. } \\
& \begin{aligned}
\text { 1. } & 3 y-x-9=0 \text { and } y-3 x+9=0 \\
\text { 2. } & 2 y-x-7=0 \text { and } y-3 x+3=0 \\
\text { 3. } & 2 y-4 x-4=0 \text { and } 4 y+2 x+4=0 \\
\text { 4. } & 3 y-3 x-3=0 \text { and } 2 y-5 x-5=0
\end{aligned}
\end{aligned}
$$

Find a pair of straight line that perpendicular to each other. Give reasons to your answer.

\section{FIGURE 3 An Example of Problem in MRA Post-test}

Most of the students gives correct solution to that problem, although there are still some of them unable to complete this task. Some of them proposed detail and complete solution. Others work efficiently but not include reason or explanation. Overall, most of the students understand enough the properties of gradient.

\section{The improvement of Students MRA}

The improvement of students' MRA is measured by N-gain [16] displayed in Table 4. Overall, score of MRA post-test of the students at JPBL class is almost twice the MRA pre-test though $\mathrm{N}$-gain belongs to the mediocre category [15]. This means that math teachers still have the opportunity to improve students' mathematical representation skills, perhaps through continuous trial of problem-solving activities that driven students to elicit their ability in mathematical representation.

\begin{tabular}{lrrrr}
\multicolumn{5}{c}{ TABLE 4. Students' MRA N-gain in JPBL Class } \\
\hline $\begin{array}{l}\text { MUA } \\
\text { Test }\end{array}$ & N & Mean & $\begin{array}{c}\text { Std. } \\
\text { Deviation }\end{array}$ & N-gain \\
\hline Pre & 158 & 7.00 & 1.184 & \\
Post & 158 & 12.66 & 2.271 & 0,283 \\
\hline
\end{tabular}

Further research with larger sample is needed to investigate whether students' mathematical representation ability can significantly reach high category.

\section{CONCLUSION}

Conclusion drawn from the research:

1. The student in JPBL class get better achievement in mathematical representation ability than their counterpart in conventional one.

2. The students' performance in solving mathematical problems is better in JPBL class then in Conventional one. The students faced difficulties at the aspect of presenting the problem in pictures and explaining graph and table. Meanwhile, the students' performance is best at the aspect of presenting the problem in mathematical equation.

3. Mathematical representation ability of the students in JPBL class improved significantly. Their MRA belongs to mediocre category.

\section{Acknowledgment}

This research was supported by the Ministry of Research, Technology and Higher Education (KEMENRISTEK-DIKTI) of the Republic of Indonesia. The authors are thankful to Rector of Universitas Negeri Medan, Research Director, and Dean of Faculty of Mathematics and Natural Sciences for providing necessary facilities to conduct the research.

\section{REFERENCES}

[1] Indonesian Ministry of Education and Culture, "Kurikulum 2013". Jakarta: Kemendikbud, 2013.

[2] National Council of Teachers of Mathematics, "Principles and Standards of School Mathematics". Reston, VA: NCTM, 2000. 
[3] Indonesian Ministry of National Education, "Permendiknas, No. 23". Jakarta: Kemendiknas, 2006.

[4] Anderson, Anderson, L.W., et al. A Taxonomy for Learning, Teaching, and Assessing. New York: Addison Wesley Longman, Inc., 2001.

[5] Hiebert, J. dan Carpenter, T.P. Learning and Teaching with Understanding. Dalam Grouws, DougSAS A. (Ed). Handbook of research on mathematics teaching and learning: A project of the National Council of Teachers of Mathematics. (pp. 65-97). New York, NY, England: Macmillan Publishing Co, Inc., 1992.

[6] Carpenter, T.P., dan Lehrer, R. Teaching and Learning Mathematics with Understanding. Dalam Fennema, E. Dan Romberg, T.A. (eds). Mathematics CSASsrooms that Promote Understanding. Mahwah: Lawrence Erlbaum Associates, Inc., 1999.

[7] Schoenfeld, A., H. Reflection on Doing and Teaching Mathematics, dalam Mathematical Thinking and Problem Solving, Schoenfeld (eds). New Jersey: Lawrence Erlbaum Associates Publisher, 1994.

[8] Minarni, A., Napitupulu, E.E., Husein, R. Mathematical Understanding and Representation Ability of Public Junior High School in North Sumatera. Journal of Mathematics Education IndoMS: vol. 7 No. 1 pp. 43-56, 2016.

[9] Ronis, D., L. Problem-based Learning for Math \& Science; Integrating Inquiry and the Internet. California: Corwin Press, 2008

[10] Mullis, I.V.S. \& Martin, M.O. (2012). TIMSS in Perspective: Lessons Learned from IEA's Four Decades of International Mathematics Assessment. TIMSS \& PIRLS International Study Center Lynch School of Education, Boston College.

[11] Arends, R. I. (2004). Learning to Teach, $6^{\text {th }}$ Ed. Boston: McGraw Hill.

[12] Puri, A. (2014). How to Create Joyful Learning in the Classroom. Available online: www.howtolearn.com.

[13] Minarni, A., Napitupulu, E.E. Developing Instruction Material Based on Joyful PBL to Improve Students Mathematical Representation Ability. Canadian Center of Science and Education: Vol. 10, N0. 9, 2017.

[14] Schmidt, H.G., et. al. Problem-Based Learning in Compatible with Human Cognitive Architecture: Comentary on Kirschner, Sweller, and Clark (2006). Esucational Psychologist, 42(2), 91-97.

[15] Resnick, L. B. Education and Learning to Think. Washington DC: National Academic Press, 1987.

[16] Hake, R. R. Interactive-Engagement Versus Traditional Methods: A SixThousand-Student Survey of Mechanics Test Data for Introductory Physics Courses. Am. J. Phys., 66(1), P.65, 1998. 